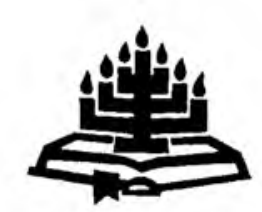

\title{
Waarderingswoord
}

\section{Christi Coetzee - 'n begaafde teoloog}

\author{
G.J.C. Jordaan \\ Skool vir Bybelwetenskappe en Bybeltale \\ Potchefstroomse Universiteit vir CHO \\ POTCHEFSTROOM
}

Dit is vir my 'n voorreg om 'n kort waarderingswoord te skryf oor my leermeester, vriend en kollega, Christi Coetzee. In die laat sewentigerjare het ek as teologiese student by die Teologiese Skool te Potchefstroom gesit aan die voete van prof. Christi, soos hy allerweë bekend is, en die Nuwe-Testamentiese wetenskap van hom geleer. Sedert 1989 was ek weer saam met hom by die Teologiese Skool, hierdie keer as kollega in die departement Nuwe-Testamentiese vakke. Om 'n mens se vroeëre leermeester later as kollega en as vriend te leer ken, is ' $n$ vreugde wat vir min mense beskore is. Daarom is dit vir my ' $n$ vreugde om, noudat hy in 1998 geëmeriteer het, 'n woord van waardering te skrywe.

Johannes Christiaan Coetzee is op 2 Mei 1936 gebore as die vierde jongste kind van wyle prof. J. Chris Coetzee, bekende opvoedkundige en rektor van die PU vir CHO vanaf 1953 tot 1963, en mev. Aletta Coetzee, gebore Van Rooy. Prof. Coetzee is 'n nasaat van Dirk Coetzee wat in 1679 van Kampen, Nederland, na die Kaap gekom het. As een van die eerste vryburgers het Dirk Coetzee in 1862 sy eie plaas aangelê, genaamd Coetzenburg - nou nog die beroemde Coetzenburg by Stellenbosch.

Van geboorte af is Christi 'n Potchefstromer (tot op hede het hy nog net sewe jaar elders gewoon), maar het tog besondere bande met die "Dopper"-streek van Noordoos-Kaapland. Sy vader was afkomstig van Venterstad en sy moeder van Steynsburg. Boonop het Christi sy vrou in Burgersdorp gaan "haal": Susanna Elisabeth Sophia (Susan) Coetsee (met 'n s).

Christi het skoolgegaan op Mooirivier Laerskool (vandag woon hy steeds regoor die skoolterrein!) en voltooi sy skoolloopbaan (1949-1953) aan die Potchefstroomse Gimnasium met onderskeidings in Latyn, Wiskunde en Geskiedenis. 
Op sportgebied het hy in krieket gepresteer, later ook in hokkie. Vir tien jaar lank het hy vir die PUK se eerstespanne krieket en hokkie gespeel, vir laasgenoemde was hy vier jaar lank kaptein. Meermale is hy gekies vir WesTransvaal se provinsiale spanne in krieket en hokkie, maar omdat hy geweier het om op Sondae te speel, het hy die eer elke keer afgewys!

Van 1954 tot 1963 studeer Christi ononderbroke aan die PU vir CHO. Sy aanvanklike plan was om onderwyser in Latyn te word. In Mei van sy derde jaar word die roeping egter te sterk en skakel hy oor na propedeutiese studie. Op daardie stadium het hy reeds Grieks saam met Latyn geneem, maar die benodigde Semitiese Tale I en II het nog ontbreek. Dié twee jaar se studie voltooi hy in 'n tydperk van bykans ses maande - en slaag steeds sy B.A. met onderskeidings in sy hoofvakke, Grieks en Latyn! In 1957 slaag hy ook Grieks Honneurs met onderskeiding, terwyl hy reeds met sy eerste studiejaar in teologie voortgaan. Sy teologiese studie voltooi hy in 1960, en word aangewys as die beste student van sy klasgroep. Hy was egter nie 'n tipiese "akademiese wrak" nie: hy presteer steeds op sportgebied, is aktief in die studentelewe en dien van 1956 tot 1957 op die Studenteraad van die PUK.

Na die afhandeling van sy Th.B.-studie het Christi nie direk tot die bediening toegetree nie. Hy voltooi eers sy magistergraad in teologie (1961) en ook sy doktorsgraad (1963) onder leiding van wyle prof. Willie Snyman met 'n proefskrif getiteld "Volk en Godsvolk in die Nuwe Testament. 'n Eksegetiese studie". Hierdie proefskrif was van so 'n hoë gehalte dat dit in 1965 deur die Nasionale Raad vir Sosiale Navorsing (nou RGN) uitgegee is.

In 1964 word die jeugdige doktor Christi Coetzee beroep en bevestig as predikant van die Gereformeerde Kerk Pietersburg. Na bykans vier jaar in Pietersburg, volg hy in 1967 'n beroep na Paarl/Stellenbosch op. Daarvandaan word hy in 1971 beroep na die Teologiese Skool Potchefstroom om NuweTestamentiese vakke te doseer, eers as senior lektor en vanaf 1974 as professor. Van 1977 af is Christi departementshoof van die Nuwe-Testamentiese vakke en in 1980 word hy aangewys as rektor van die Teologiese Skool (1980-1982). Hy tree ook op as Adjunkdekaan (1980-1982) en later as Dekaan (1983-1985) van die Fakulteit Teologie.

As dosent het prof. Christi homself onderskei as 'n skerp eksegeet wat die kleinste besonderheidjie in ' $n$ Bybelteks raaksien en die gawe het om dit terselfdertyd binne die perspektief van die breë openbaringshistoriese lyne te plaas. Hiervan kan elke teologiese student wat onder sy hande deurgeloop het, getuig (en dit sluit die meeste huidige Gereformeerde predikante in!).

Sonder twyfel is Christi 'n akademikus van formaat. Behalwe sy proefskrif het 'n hele aantal monografieë uit sy pen verskyn, onder andere: Die teks van die $\mathrm{Ou}$ en die Nuwe Testament (1976), Lewende water! Twee reekspreke uit die 
Evangelie en Eerste Brief van Johannes (1980), Die blye boodskap - Gids deur die boeke van die Nuwe Testament (1983). Sommige van sy werke is ook in Engels uitgegee: Route map to the books of the New Testament (1995), The canon of the New Testament (1995) en Hermeneutics and exegesis of the New Testament (1997). Hy het 23 artikels geskryf wat in geakkrediteerde vaktydskrifte verskyn het asook verskeie bydraes in die publikasiereekse van Wetenskaplike Bydraes van die PU vir CHO en studiestukke van die IRS (IBC).

In 'n huldigingsbundel vir prof. Floor (Koninkryk, Gees en Woord, 1988) waarvan Christi self die redakteur was, skryf hy 'n hoofstuk waarin hy 'n uiteensetting gee van een van sy groot bydraes tot die Nuwe-Testamentiese wetenskap: Gedagtestruktuurontleding en die eksegese van die Heilige Skrifte. Hy was ook redaksielid van die uiters belangrike Handboekreeks Handleiding by die Nuwe Testament waarvan ses dele tussen 1978 en 1990 verskyn het en wat later ook in Engels uitgegee is. Self het Christi in hierdie reeks die hoofstukke geskryf wat handel oor die pneumatologie en eskatologie in die prediking van Paulus (Band V) en oor die Johannes-evangelie, die briewe van Johannes en die boek Openbaring (Band VI). Daarmee het hy homself uitgewys as 'n Suid-Afrikaanse outoriteit op die Johannese geskrifte. Sedert 1984 is hy deur die Bybelgenootskap van Suid-Afrika benoem as lid van die Eindredaksie van die Afrikaanse Bybelvertaling asook lid van die Advieskomitee van die Bybelgenootskap.

Nie net in Suid-Afrika nie maar ook in die buiteland het hierdie briljante akademikus die oog gevang. In 1975 was Christi die organiseerder van die Eerste Internasionale Konferensie van Christelike Hoër Onderwysinrigtings. Met die oog daarop het hy 22 lande en 5 kontinente deurreis. Daaruit het voortgevloei nie minder nie as 57 openbare voordragte wat hy in die buiteland gelewer het. Die jongste hiervan was toe hy in 1994 vir twee maande lank opgetree het as voltydse gasprofessor aan die Evangelische Theologische Faculteit van die Rooms-Katolieke Universiteit te Leuven in België.

Deur die jare was Christi lid van verskeie vakverenigings waar hy 'n gewaardeerde bydrae gelewer het en nog lewer. Hy is 'n stigterslid van die NuweTestamentiese Werkgemeenskap van Suid-Afrika, 'n stigterslid en die eerste voorsitter van die Nuwe-Testamentiese Werkgemeenskap van Potchefstroom, lid van die Gereformeerde Teologiese Vereniging van Suid-Afrika, assessorlid van die Suid-Afrikaanse Akademie vir Wetenskap en Kuns en, les bes, lid van die uiters gesogte internasionale vakvereniging, Studiorum Novi Testamenti Societas.

Christi het sy kundigheid nie net vir die akademiese wêreld gereserveer nie. Sedert 1964 het hy vir die Gereformeerde Kerke in Suid-Afrika gedien as lid of voorsitter van studiedeputate oor verskeie sake. Hy is 'n begaafde prediker wat, waar die geleentheid hom voordoen, die Woord van die Here in Gereformeerde 
gemeentes verkondig. By vier geleenthede was hy ook amptelike afgevaardigde van die GKSA na sinodes van buitelandse kerke waarmee die GKSA in korrespondensie staan. Intussen het hy sy kundigheid ook tot beskikking van die breër kerklike gemeenskap gestel deur 'n groot aantal artikels oor 'n wye verskeidenheid van onderwerpe te skryf in kerklike tydskrifte soos Die Kerkblad, Die Gereformeerde Vroueblad en Die Almanak van die GKSA.

Te midde van akademiese erkenning het Christi steeds 'n nederige en diep gelowige mens gebly. Kenmerkend van sy werk is juis dat hy deurgaans vashou aan die opregte belydenis dat die Bybel die gesagvolle, geïnspireerde, onfeilbare Woord van God is. Sy werk aan die Teologiese Skool was vir hom steeds die hoogste prioriteit. Sy studente het altyd 'n besondere plek in sy hart gehad. Hiervan getuig die woorde waarmee hy sy jongste studiegids vir Eksegesestudente afsluit:

Mag Eksegese van die Nuwe Testament in 1997 vir elkeen van julle (en vir my!) ryke seën van die Here inhou. Mag dit besonderlik inhou 'n verdieping van ons verstaan van en insig in die skatte van die Here ons God se openbaring in sy Heilige Skrifte."

Christi het ook gesinsmens gebly. Die vyf kinders wat uit sy en Susan se huwelik gebore is, is selfs nou dat hulle al uit die huis uit is, vir hom 'n gawe uit die hand van die Here. As hy die kans kry, glip hy vir 'n naweek saam met sy familie weg na hulle plasie aan die oewer van die Vaalrivier. Noudat die tyd vir hom aangebreek het om te emeriteer, sal hy waarskynlik meer kans kry om op sy geliefde plasie deur te bring.

Vir 27 jaar het die Here Christi Coetzee gebruik as bruikbare dienskneg aan die Teologiese Skool in Potchefstroom. Saam met hom en Susan kyk al sy kollegas met dankbaarheid terug op 'n lang en geseënde pad. Ons bede is dat die Here hom nog lank mag spaar vir sy dierbares en vir almal wat met hom saamgewerk het. Mag die besondere gawes wat hy ontvang het, steeds in diens van die kerk en samelewing en tot uitbreiding van die koninkryk van God aangewend word. 